\title{
Development of Three-Dimensional Media for Bindly Students in Social Sciences
}

\author{
Sukma Perdana Prasetya ${ }^{1, *}$ Ali Imron ${ }^{2,}$ Riyadi $^{3}$ \\ ${ }^{1,2,3}$ Universitas Negeri Surabaya \\ ${ }^{*}$ Corresponding author. Email: sukmaperdana@unesa.ac.id
}

\begin{abstract}
This research focuses on developing learning media in the form of three-dimensional media regarding the shape of the earth's surface. The media developed is guided by the material in Social Sciences in Junior High School. For students with special needs, especially for blind students, this three-dimensional learning media is very useful because blind students do not just imagine the material of the earth's surface, but through three-dimensional media, blind students can touch, feel, and feel directly. how the shape of mountains, hills, rivers, lakes, and so on. The development procedure uses the Plomp model. This research was carried out for two years with the following stages: Year 1 (needs analysis, design, construction realization), and Year two (implementation, evaluation, dissemination). At this time the research is still in its first year. Data collection techniques in this study were interviews and questionnaires through Forum Group Discussion (FGD) activities which were attended by 20 IPS MGMP teachers. The FGD was carried out after the media received a feasibility assessment from material experts and media experts. The FGD activity was carried out with a number of 20 teachers to obtain direct responses by demonstrating 3D learning media on the material for the diversity of forms of the earth for grade VII junior high school education. The results of the study indicate the feasibility of the material expert on average 3.65 which is included in the very feasible category. The response from the social sciences teacher assessed that 3D media was very good (percentage with $85.68 \%$ ) to be used in social sciences learning material on the shape of the earth. They also consider 3D media to be very helpful in learning, especially for blind students because they can learn by means of the senses of feeling, touching, touching directly on three-dimensional media.
\end{abstract}

Keywords: $3 D$ media, the blind, the earth

\section{INTRODUCTION}

Learning in the classroom should be directed at a series of activities that involve students to be active directly. Such a learning experience will provide more value than just listening to the teacher's explanation. Prasetya et al [1] stated that learning activities can be carried out through three ways of learning. The first way, conveying information verbally or with the lecture method. The second way, learning through real experience, for example by inviting students to the field to observe and interact directly with the object as the material or material being studied. This method can be considered effective but has many obstacles in its implementation, such as cost and time. The third way, using the media as a means for learning activities.
Teachers in conveying material, especially regarding the surface of the earth to students so that it is notabstract, the use of media in learning is one of the requirements that must be met. Furthermore, Prasetya [2] argues that in studying the geosphere phenomenon, media is needed that can provide a picture or example ofa real or artificial situation in a representative presentation.

This research focuses on developing learning media in the form of three-dimensional media regarding the shape of the earth's surface. The media developed is guided by the material in Social Sciences in Junior High School. This three-dimensional learning media can help in increasing students' understanding in recognizing the geosphere phenomenon because it makes learning material from abstract to concrete. For students with special needs, especially for blind students, this three- 
dimensional learning media is very useful because blind students do not just imagine the material of the earth's surface, but through three-dimensional media, blind students can touch, feel, and feel directly. how the shape of mountains, hills, rivers, lakes, and so on.

Due to limited vision, blind students never see directly about the formation of the earth's surface, they know information about the forms of the earth through explanations from other people. Through this threedimensional media, blind students will have new experiences by touching directly how the representation of the earth's surface is reduced.

In fact, in everyday life, blind students cannot directly witness the shape of the earth's surface in the universe. Due to limited vision, they can only imagine how the real composition of the earth's surface is, making it very difficult to learn. Such conditions indicate that learning media in the form of three dimensions in teaching and learning activities is an important factor. The threedimensional media in the form of miniature forms of the earth's surface that was developed is expected to attract students' attention and avoid misconceptions. Threedimensional media can also overcome the limitations of space, time, and observation because not all objects, objects, and events can be brought into the classroom. The use of three-dimensional media is expected to make it easier for students to study Social Sciences, especially on the material diversity of the earth's surface.

The media selection model provides a threedimensional illustration that makes it appear real in a smaller size so that it can easily understand shapes and characteristics and turn something abstract into reality. This three-dimensional media is pursued in order to facilitate learning activities. The existence of this media replaces field observation activities which usually require a lot of time and money. Learning activities can still be carried out in class by presenting a natural replica that describes a unit of the real face of the earth without having to leave the classroom.

This research is still in the development stage and has not yet gone through the implementation stage. At this stage of the study, it aims to: describe the feasibility of learning media in the form of a three-dimensional face shape in Social Science lessons in junior high school (SMP) and determine the response of social sciences teachers.

\section{METHODS}

This research is still in the stage of developing 3D learning media on the material of the shape of the earth in the social sciences subject for class VII, this research has not yet been implemented, especially for blind students. The development of 3D learning media will be carried out at the State University of Surabaya. Data collection techniques in this study were interviews and questionnaires through the Forum Group Discussion
(FGD) to social science subject teachers to determine the condition of the class during the teaching and learning process without learning media and student learning outcomes in social sciences subjects. The FGD activity was carried out with a number of 20 teachers to obtain direct responses by demonstrating $3 \mathrm{D}$ learning media on the material for the diversity of forms of the earth for grade VII junior high school education.

The research procedure used in the development research for 3D learning media on the material of the earth's surface. This 3D learning media development research uses a one-shot case study research design. The design of the one-shot case study can be described as follows:

$\mathrm{X}-\mathrm{O}$

$\mathrm{X}=$ demonstrating the use of three-dimensional media

$\mathrm{O}=$ observation, by carrying out a questionnaire from

the teacher's response.

The data analysis technique used in this study is to provide answers to the development of 3D learning media through validation data analysis. material experts and media experts using a Likert scale to test the feasibility of media and teacher response analysis to determine the effectiveness of using media.

The development procedure uses the model Plomp [1]. This research was carried out for two years with the following stages:

Year 1 (needs analysis, design, construction realization), and Year two (implementation, evaluation, dissemination). At this time the research is still in its first year.

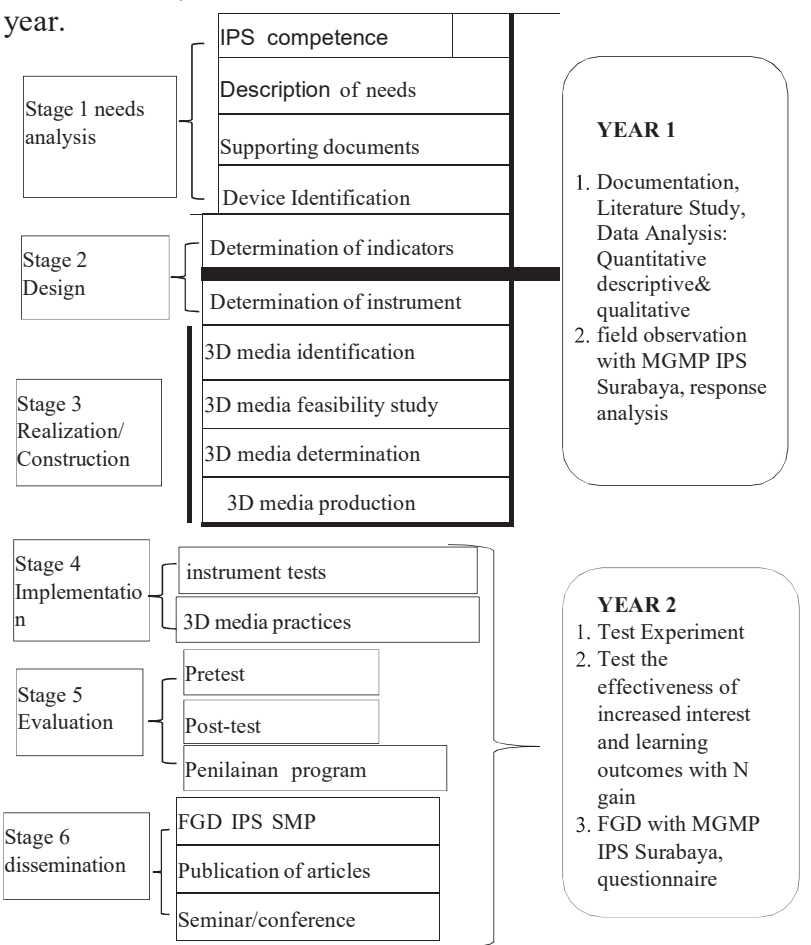

Figure 1 Research stages year 1 and year 2 


\section{RESULTS AND DISCUSSION}

\subsection{Results}

This research and development $(\mathrm{R} \& \mathrm{D})$ consist of six sequential stages, starting from Year 1 (needs analysis, design, construction realization), and Year two (implementation, evaluation, dissemination) which was adapted from Plomp's [3].

\subsubsection{Needs Analysis}

In this stage, identification of problems and needs in the implementation of social sciences learning material on the shape of the earth is carried out in junior high school. In this stage, the needs analysis becomes the basis for collecting data used in observation and documentation. Observation is used to collect data related to the needs of blind students to the desired threedimensional media. Documentation data in the form of interviews with blind students, literacy studies on basic competencies and indicators as well as social sciences material for junior high school students.

\subsubsection{Student Need Analisys}

Based on interviews with teachers who teach blind students, information was obtained that students who have visual impairments have difficulty understanding social sciences material. So far, social sciences learning materials have only been delivered through oral explanations without being able to convey the material through visual media. Limitations in visual media for blind students make it difficult for students to understand the material on the shape of the earth's surface, they only imagine without ever knowing the real shape. Threedimensional media of the shape of the earth's surface that can be touched and felt directly can help blind students in understanding the actual shape of the earth's surface more concretely.

\subsubsection{Analysis of Learning Objectives}

Learning objectives must be clearly formulated at this stage. Learning objectives provide a direction for the perpetrators of learning activities. The formulation of indicators of achievement of competencies and learning objectives in this study limits and focuses on the Learning Implementation Plan (RPP) for social sciences subjects that have been prepared by the teacher. The formulation of learning objectives is clearly described as follows:

- Competency standards: Describe the diversity of forms of the earth's surface, the process of formation, and their impact On life

- Achievement Indicators: Identifying the diversity of landforms of the earth

- Theme: Chapter 1 People, Places and Environment

- Sub-theme: Physical State of Indonesia

- Material: Shape of the Earth

\subsubsection{Design}

Based on the description and indicators of social sciences learning in junior high school, the material for the shape of the earth and interviews with teachers and teachers of blind students can be identified how to design three-dimensional media for the shape of the earth. The beginning of the preparation of this media by making a rough sketch design so that the media format is obtained in the form of an ideal presentation. The shape of the earth's surface is presented in three-dimensional media in the form of mountains, mountains, plateaus, hills, rivers, waterfalls/rapids, lakes, lowlands, meandering rivers, fault zones, and folds.

\subsubsection{Realization/Construction}

At this stage, the stage is to produce a product and to get validation from several experts, including media experts and material experts. So at this stage, the researcher will get a media revision depending on the opinion of media and material experts.

The media feasibility assessment was carried out on August 7, 2021, by media experts and material experts. The results of the media feasibility assessment using a four-category Likert Scale adapted from Mardapi [4] are as follows.

Table 1. Media validation results by media experts discussion

\begin{tabular}{|l|l|l|l|}
\hline No & Aspects of assessment & Average & Description \\
\hline 1 & Content eligibility & 3,6 & Very feasible \\
\hline 2 & Media characteristics & 3,5 & Very feasible \\
\hline 3 & Instructional aspects & 3,8 & Very feasible \\
\hline & Total & 11,1 & \\
\hline & Average & 3,7 & Very feasible \\
\hline
\end{tabular}

The media feasibility assessment by material experts was carried out on August 4, 2021, with the following results. 
Table 2. Media validation results by material experts

\begin{tabular}{|l|l|c|c|}
\hline No & \multicolumn{1}{|c|}{ Aspect Rating } & Average & Description \\
\hline 1 & Feasibility of content & 3.5 & Very feasible \\
\hline 2 & Feasibility of presentation & 3.8 & Very feasible \\
\hline & Total & 7.3 & \\
\hline & Average & 3.6 & Very feasible \\
\hline
\end{tabular}

After going through the feasibility test by the media and material experts, then a Forum Group Discussion (FGD) was held. This FGD was attended by 20 teachers from MGMP IPS Surabaya. In the FGD activity, a demonstration of the use of three-dimensional media for the shape of the earth's surface was carried out. After the MGMP teachers listened to the use of threedimensional media, the teachers were asked to provide responses and perceptions about the use of threedimensional media. Student responses and perceptions are needed to know quantitatively how the social sciences teachers react to the presence of threedimensional media. The results of the media demonstration activity stated that the average value of the teacher's response was $85.68 \%$, based on the Likert Scale table with five criteria [5]. the value of $85.68 \%$ is included in the "Very Good" category. The following is a table of teacher responses to the use of threedimensional media in the form of the earth's surface.

Table 3. Results of social sciences teacher response recapitulation

\begin{tabular}{|l|l|l|l|}
\hline \multicolumn{1}{|c|}{ Indicator } & \multicolumn{1}{|c|}{ Note } \\
\hline 1 & Encouraging interest in learning about the material being studied & 90 & Very Good \\
\hline 2 & Stimulating curiosity & 84 & Very Good \\
\hline 3 & Encouraging independent learning activities & 78 & Good \\
\hline 4 & Encouraging active learning & 84 & Very Good \\
\hline 5 & Encouraging students to work according to the material being studied & 70 & Very Good \\
\hline 6 & Encouraging the feeling to understand the material easily & 86 & Very Good \\
\hline 7 & Encouraging self-confidence to understand the learning material & 85 & Very Good \\
\hline 8 & Feeling happy after learning & 85 & Very good \\
\hline 9 & Feeling satisfied after learning activities & 87 & Very Good \\
\hline 10 & Clarity of the material presented & 89 & Very Good \\
\hline 11 & Interesting learning media & 88 & Very good \\
\hline 12 & Adding insight for students & 88 & Very Good \\
\hline 13 & Interest in the material & 90 & Very Good \\
\hline 14 & Provides positive reinforcement & 87 & Very good \\
\hline Total & & 1199 & Very Good \\
\hline Average & 85.68 & & \\
\hline
\end{tabular}

\subsubsection{Implementation}

In this stage is the implementation of learning in blind students material for the shape of the earth's surface using a three-dimensional model (not yet implemented/will be implemented in 2022).

\subsubsection{Evaluation}

Evaluation of the model is carried out to see the effectiveness and efficiency of the application of learning with three-dimensional media. Evaluation is carried out at each stage of the activity so that it can be determined the implementation of each stage before moving on to the next stage. At the final evaluation stage, a student's cognitive ability test is carried out by giving the student worksheets. evaluation design using one group pretest-posttest (not yet implemented/will be implemented in 2022).

\subsubsection{Dissemination}

Dissemination of research results is carried out through 1). implementation of FGD which invited 20 
MGMP IPS Surabaya teachers, 2) publish through national articles, 3) publish through international articles, 4) publish through seminars on results and international conferences (not yet implemented/will be implemented in 2022).

\subsection{Discussion}

The development of three-dimensional solar system media has gone through the validation stage before being used in learning activities. The validation process aims to determine the level of media feasibility. The process of assessing or validating the feasibility of the media is carried out by media experts and material experts. This assessment will determine the level of feasibility of the three-dimensional media of the shape of the earth that will be used in learning social sciences subjects. This feasibility assessment is based on the Likert scale that has been described by Sugiyono [5].

The assessment that has been carried out by media expert validators and material experts to determine the feasibility of the media gets an average score of 3.7 so that it is included in the very feasible criteria. The criteria described by Riduwan [6] regarding the percentage of eligibility. The feasibility assessment carried out is very important because it aims to determine the feasibility level of the media. The media deserves to be used as teaching materials for the learning process. Three-dimensional media can encourage students to achieve the expected competencies.

The importance of using media in the learning process is reinforced by the opinion of Dale who put forward the experience cone theory in Prasetya [7] which states that learning success is measured by the level of learning experience obtained by students depending on their treatment in learning. Both the treatment of teachers/lecturers or student activities when studying.

Further explained that the treatment in learning will affect the learning experience. The more abstract treatment in learning, for example with lectures that use symbols, learning by reading, then the learning experience gained is not too great. With the use of media in the learning process that leads to direct activities, the learning experience will be obtained optimally.

Cone Dale's opinion can be concluded if learning media that provide direct experience will be easier for students to understand than media that use verbal symbols. The three-dimensional model of the earth's surface can provide benefits for students to interact directly using the three-dimensional media. The use of concrete media can improve student learning outcomes to the maximum, especially in social sciences subjects.

Based on the results of the limited responses conducted to the IPS Surabaya MGMP teachers who have been programmed to participate in FGD activities, social sciences teachers were asked to fill out a perception questionnaire to find out their opinion on the attractiveness of the media. This media assessment of social sciences teachers aims to determine the level of teacher interest in the media to be used in social sciences learning. The results of the social sciences teacher assessment in the perception questionnaire on the attractiveness of the media, get a percentage value of $80 \%$ so that it is included in the attractive criteria. The developed 3D face shape media can attract the attention of teachers and is suitable for use in the social sciences learning process in junior high school.

The social sciences teacher responded that threedimensional learning media will be able to increase student interest and learning outcomes because it is made to make abstract material concrete. Concrete material through three-dimensional media is also very helpful in the learning process for blind students. According to McCall[8], blind students must learn through other senses; feel, touch, smell, and listen.

Three-dimensional media can facilitate blind students to be able to feel, touch and feel the shape of the earth's surface directly. Media Three-dimensional model is an important visual media in presenting spatial objects on the earth's surface. According to Fansury et al. [9], Visual media is important for processing information about the spatial location of objects and object characteristics such as shape, size, weight, and texture.

For blind students, three-dimensional media is a visualization of the shape of the earth's surface in a real form. According to Natarajan [10], construction planning emerges theoretical knowledge in visual media about the interaction between place and space (spatial) being built. Blind students can find out material in the real form in three-dimensional mock representations and can increase student interest in learning and get better learning outcomes than before [11]. Three-dimensional model media can be applied in the form of a demonstration method to enable blind students. The application of learning methods as shown by active media has significant advantages compared to conventional teaching methods [12];[13]. The media selection model provides a three-dimensional illustration that makes it appear real with a smaller size in order to easily understand shapes and characteristics and turn something abstract into reality.

\section{CONCLUSION}

The results of research and discussion regarding the development of 3D media on the material of the earth's surface for social sciences subjects, it can be concluded that:

- The three-dimensional media that has been developed has received a feasibility assessment by learning media experts with an average value of 3.7 and from material experts it gets 3,6 , then the average score obtained from the two validators is 3.65. Values of 3.65 based on a Likert scale 
included in the range $X \geqslant 3.00$, so it is classified as "very decent".

- Teacher responses to the 3D media get an average value of $85.68 \%$. From the average value, it is in the range of $80-100 \%$ which is included in the "very good" category.

\section{REFERENCES}

[1] S. P. Prasetya, E. and Budiyanto, and Daryono, "Media development effectiveness of geography 3d muckups," J. Phys. Conf. Ser., vol. 953, no. 01, pp. $\quad 1-6, \quad 2017$, doi: 10.1088/17426596/953/1/012172.

[2] S. P. Prasetya, "Effect of Learning Media Variation to Increase Interest and Learning Outcomes of Geography," vol. 212, no. Icei, pp. 558-561, 2018, doi: 10.2991/icei-18.2018.122.

[3] T. Plomp, Educational and Training System Design. Enschede: University of Twente, 1997.

[4] D. Mardapi, Teknik penyusunan instrumen tes dan nontes. 2008.

[5] Sugiyono, Metode Penelitian dan Pengembangan Pendekatan Kualitatif, Kuantitatif, dan R\&D. 2015.

[6] Riduwan, "Metode dan Teknik Menyusun Skrisi dan Tesis," Bandung Alf., 2015.

[7] S. P. Prasetya, Learning Media of Geography. Yogyakarta: Ombak, 2014.

[8] H. McCall, Stephen. Mason, Visual Impairment: Access to Education for Children and Young People. 1997.

[9] A. H. Fansury, N. Lutfin, and S. N. Arsyad, "Audio Books as Teaching Media To Blind Students In Learning Efl,” Klasikal J. Educ. Lang. Teach. Sci., 2019, doi: 10.52208/klasikal.v1i1.4.

[10] L. Natarajan, "Socio-spatial learning: A case study of community knowledge in participatory spatial planning," Prog. Plann., 2017, doi: 10.1016/j.progress.2015.06.002.
[11] A. Lobben and M. Lawrence, "The Use of Environmental Features on Tactile Maps by Navigators Who Are Blind," Prof. Geogr., 2012, doi: 10.1080/00330124.2011.595619.

[12] D. R. P. Sitompul and P. Sihombing, "A teaching media of using the busy bit and SDCC in displaying character string on LCD in MCU 8051 IDE," Alexandria Eng. J., pp. 1-6, 2016, doi: 10.1016/j.aej.2017.01.037.

[13] A. Garrote, F. Felder, H. Krähenmann, S. Schnepel, R. Sermier Dessemontet, and E. Moser Opitz, "Social Acceptance in Inclusive Classrooms: The Role of Teacher Attitudes Toward Inclusion and Classroom Management," Front. Educ., 2020, doi: 10.3389/feduc.2020.582873. 